\title{
In Larger Freedom
}

\section{Access to Information and International Government Organization Archives}

\section{Jim Church}

n April 2019 at the International Studies Association (ISA) annual conference, I participated in a panel about International Organization Archives and the UN Depository system. ${ }^{1}$ There we learned of a report by the Joint Inspection Unit (JIU) of the United Nations titled "Strengthening Policy Research Uptake in the Context of the 2030 Agenda for Sustainable Development." The report notes that "the research value and visibility of United Nations digital outputs, which are currently residing, unconnected, on numerous United Nations websites and in a plethora of diverse, online databases" presents challenges to researchers. They also recommend that "a principle of open access should operate by default for research products and data published or commissioned by the United Nations. This includes publications, authorship and co-authorship in open access journals or collections." ${ }^{2}$ Per their mission statement, the JIU is the "only independent external oversight body of the United Nations system mandated to conduct evaluations, inspections and investigations system-wide."3

That is welcome news if the United Nations Department of Public Information agrees; to date, their practice of pay-walling UN Sales Publications does not indicate as much. But charging for publications is not the full extent of the UN Access to Information (AI) problem: researchers also complain about IGO archives. The way some international organizations handle requests for information, as well as a tendency to broadly classify internal communications as "confidential," can present impediments to researchers interested in the history and practices of these organizations, not to mention citizens affected by the work of UN Operations. This column offers a selective review of IGO archives and AI policies and makes tentative suggestions for reform.

\section{Research Guides to International Government Archives}

Online guides to IGO archives are not common. An informative, if dated, one can be found at the Woodrow Wilson International Center for Scholars (Wilson Center). In 2004 the author completed a survey of IGO Archives and reached out to "each of the UN specialized agencies, two UN programs (UNHCR and WFP), and two UN-related organizations (WTO and IAEA) to summarize its access policy" as well as "NATO, OECD, and the International Committee of the Red Cross and the International Federation of Red Cross and Red Crescent Societies. ${ }^{4}$ Fifteen years later the guide is still valuable for its contact information and descriptions of these policies. A current guide created by the UN Archives in New York provides listings of international government and nongovernmental organization archives and specialists, ${ }^{5}$ including the International Council on Archives (ICA) ("dedicated to the effective management of records and the preservation, care and use of the world's archival heritage") and the International Management Records Trust. ${ }^{6}$ UNESCO has published three versions of a Guide to the Archives of Intergovernmental Organizations, providing detailed information about the mission and policies of thirty-nine IGO archives. ${ }^{7}$ Each entry includes contact information, hours, languages, organizational history, collection descriptions, finding aids, and AI policies. The drawback is the latest volume was written in 1999, which predates the era of massive digitization and many changes to IGO information policies. For example, in 1999 the World Bank Archives AI policy stipulated "the World Bank Group Archives are currently classified as 'Official Use Only' and thus are normally available only to staff within the World Bank Group." ${ }^{8}$ This contrasts strikingly with the current World Bank Group's AI policy, which states that the World Bank Group "will disclose any information in its possession that is not on its list of exceptions."

\section{United Nations Archives in Geneva}

I visited the United Nations Office in Geneva (UNOG) Archives when researching League of Nations Depositories. These magnificent archives contain six linear kilometers of material, including the League of Nations Archives, archives of international peace movements, the Archives of the United Nations Office at Geneva, and a collection of related private archives. A good way to get acquainted is to browse the organizational hierarchy of the UNOG Registry, Record and Archives Unit at https://biblio-archive.unog.ch/archivplansuche.aspx. Opening the high-level fonds of the League of Nations Secretariat and drilling down is staggering. The "Economic Relations Section" from 1933-1946, for example, displays more than 175 sub-series with titles that are disquietingly familiar: "Demographic and Migration Problems," "Protection of Consumers Against Worthless Goods," "Customs Tariffs," "Import and Export Restrictions," and my favorite, "Artificial Manure." The series "Health and Social Questions" is similar, with sub-series 
on opium, vaccines, and trafficking in women and children. The archive has a catalog (https://biblio-archive.unog.ch /suchinfo.aspx) with advanced search options.

Even more interesting is the Total Digital Access to the League of Nations Archives (LONTAD) Project (https://lontad -project.unog.ch/) launched by the UNOG Library Institutional Memory Section. This stupendous undertaking aims to preserve and provide online access to the more than 15 million pages of archival documents, requiring more than $250 \mathrm{~TB}$ of data. Some material is already available: if a user goes to the UN Enterprise Search Engine (https://search.un.org) there is a pull-down menu limiting the search to League of Nations content. I also like the simplicity of their AI policy: "The Archives of the League of Nations are entirely accessible" and "United Nations records over 20 years old are generally open for public research, unless the classification level 'Strictly Confidential' (or related) applies." ${ }^{\prime 10}$ This is important because the archives also contain records of the UN offices currently operating in Geneva: notably the UN Economic and Social Council and the Economic Commission for Europe.

\section{United Nations Archives in New York}

The United Nations Archives in New York (a.k.a. Archives and Records Management Section, or ARMS) has an ambitious mission: in addition to organizing, digitizing, and providing access to UN historic content, they receive material from the offices at the UN Headquarters in New York on an ongoing basis. Even so, the archives are not as comprehensive as one might think. They do not, for example, include materials from the UN Specialized Agencies, such as UNESCO, nor from UN Funds and Programs like the United Nations Development Programme. ${ }^{11}$ That said, ARMS is an ideal place to research the UN's political and administrative history, UN Peacekeeping Operations and Field Missions, or the UN's origins. A good way to get oriented is to browse the Finding Aids at https://archives.un.org /content/finding-aids-0, which groups the archives into four broad categories: Archives of the Secretaries General, Archives of Secretariat Departments (e.g., Departments of Economic and Social Affairs), UN Field Missions (including observer, relief, and peacekeeping missions), and selected predecessor organizations, such as the United Nations Conference on International Organization.

The archives are organized using the hierarchical "tree structure" used by most IGO archives: fonds, sub-fonds, series, sub-series, folders, and files. The search engine https://search .archives.un.org/ retrieves metadata from the finding aids and an impressive array of digital objects (at the time of this writing more than 215,000). The search page also provides an inspiring list of archives for UN missions. Browsing through these is a fantastic way to get acquainted with the arc of UN history. What was the purpose of the first UN Peacekeeping force, the United Nations Emergency Force? Look at the finding aid to find out. An active digitization program has also recently completed two vast digitization projects for the complete archives of Ban Ki Moon and Kofi Annan. Clearly much is to be commended here.

Yet navigating an archive of this size is a challenge, even for the most dedicated and knowledgeable researcher, so it's advisable to consult with a UN archivist before making a trip. But one may encounter other obstacles. ARMS asks users to book a visit well in advance (the recommended time is four to six weeks) and to come prepared with a list of documents and a work schedule. But the most serious issue of is the extraordinary emphasis placed on "information sensitivity" and the absence of a UN AI policy. A significant amount of material seems unnecessarily classified as "confidential." The current procedures for "information sensitivity, classification and handling" are spelled out on the Secretary General's Bulletin ST/ SGB/2007/6 (SG bulletins represent the highest level of Secretariat policy) and state that

a) Records that are classified as "strictly confidential" shall be reviewed on an item-by-item basis by the Secretary-General, or by such officials as the Secretary-General so authorizes, for possible declassification when 20 years old. Those not declassified at that time shall be further reviewed, every 5 years thereafter, by the Secretary-General or by such officials as the Secretary-General so authorizes, for possible declassification.

(b) Records that are classified as "confidential" shall be declassified automatically by the Archives and Records Management Section when 20 years old. ${ }^{12}$

There are clearly situations where unauthorized disclosure of sensitive information could seriously jeopardize the work of the UN or compromise the safety and security of individuals. But the rationale seems to be anything even potentially sensitive should be restricted, and the decision to declassify has to go all the way up the chain of command to officials who seem to have wide discretion about what to release, to whom, and when. The UN Archives Management Guidance Document titled "How Do I Protect Sensitive Information?" states that “as a safeguard, you should consider all documents to be STRICTLY CONFIDENTIAL or CONFIDENTIAL until their classification is confirmed." ${ }^{33}$ There is also a seventy-seven-page "Information 


\section{In Larger Freedom}

Sensitivity Toolkit" that goes into exhaustive detail about reasons to classify documents (one is "strained relations between the United Nations and a non-governmental organization"). ${ }^{14}$

Another confusing issue is the process and timelines for declassification: in theory this is automatic and all documents classed as "confidential" get declassified after twenty years. But the ARMS metadata typically indicates the original classification status, not the current one. Thus the fond Criticisms of United Nations Operations, dating from 1961 to 1970, still says "confidential" (after almost fifty years) even though it was technically declassified twenty-nine years ago. ${ }^{15}$ Numerous other fonds, for example, the International Conference on the Former Yugoslavia (ICFY) (1992-1993), which include negotiations and ceasefire agreements, likewise indicate a confidential status. $^{16}$

An excellent (and highly critical) review of UN information practices was written by the UN Special Rapporteur of the Human Rights Council on the Promotion and Protection of the Right to Freedom of Opinion and Expression, David Kaye, director of the International Justice Clinic and Clinical Professor of Law at UC Irvine. His report at https://undocs.org /A/72/350 is worth a read. Here Kaye states,

The United Nations does not have an access-toinformation policy that applies to every department and specialized agency; it does not even have ad hoc standards to provide a response to access-toinformation requests. For the central global political institution, one that serves the public interest across a range of subject matters, this is intolerable. ${ }^{17}$

It is intolerable. What is more, the UN expects governments of nation states to "enact the necessary procedures, whereby one may gain access to information, such as by means of freedom of information legislation" when the UN itself has no such measures. ${ }^{18}$ There is no UN Freedom of Information Act. There is no clear procedure whereby the public can request information about allegations of whistle-blowing, fraud, or potential UN conflicts of interest. The Department of Public Information does have a web form via which the public may address inquiries, and on the UN Archives FAQ the answer to access to confidential documents is "please email us a list of the files you'd like access to, and our reference staff will initiate the declassification review process." But providing an email address is not the same thing as having an AI policy. And what is ironic is that international financial institutions like the World Bank and IMF (the traditional bogeys of international civil society) now have the most open AI policies. One of these is examined next.

\section{World Bank Archives}

The World Bank has made great strides in its AI policy, going from one of the most restrictive in the 1980s to the most open today. First of all, they have a policy: it is available at https:// www.worldbank.org/en/access-to-information and a brochure about it is aptly titled "Open Archives." ${ }^{\prime 19}$ There is a clear pathway to make an AI request at https://www.worldbank.org/en /access-to-information/requests, and there is even an AI annual report. For researchers needing information there is a straightforward process. Requests for information may be submitted via an AI request form. Inquiries are acknowledged within twenty-four hours with a more comprehensive response sent within twenty business days. The system is so transparent the Bank records all requests made monthly, with case numbers. If requests are denied, there is an appeal process conducted by the Access to Information Committee and the Access to Information Appeals Board.

The features on the World Bank Archives website https:// archivesholdings.worldbank.org/ are similar to the UN Archives in New York, if a bit easier to navigate. One can browse the hierarchical list of fonds by going to https://archivesholdings .worldbank.org/list-of-fonds, some of which have exhaustive metadata. Upon discovery of a series, one can often find an inventory listing of documents with their disclosure status. Sometimes the availability is obvious (press releases are public); and most are "eligible for disclosure" (a better term than "unclassified.") Per the World Bank Classification and Control Policy materials not available for disclosure include items that are "Strictly Confidential," "Confidential," or "Official Use Only." ${ }^{20}$ I spent a considerable amount of time searching the site, and found that the amount of information classified as "confidential" or "partial disclosure" was rare compared to the UN Archives. ${ }^{21}$ This is an extraordinary step forward from the policies of previous World Bank regimes (Official Use Only!) representing a great transformation towards transparency and open government.

\section{European Union (EU)}

The EU archives can be confusing for a different reason: there are a lot of them, but they are being consolidated. A list of appears on the EU page devoted to libraries and archives, but this not extraordinarily helpful as some of the links are broken and others provide minimal information. ${ }^{22}$ The major EU institutions such as the European Parliament, the European Commission, and the European Council historically had their own 
archives, some with search engines and finding aids. Access to archival content is generally governed by what is known in Europe as the "30-year rule," elaborated in EU Council Resolution No 354/83, ${ }^{23}$ which calls for automatic declassification of archival content after thirty years. EC Regulation (EC) No 1049/2001 also specifies rights of access for EU citizens (note the limitation) to European Parliament, Council, and Commission documents. ${ }^{24}$ The EU also has a useful "Freedom of Information" website that specifies rights and exceptions for access to information. ${ }^{25}$

The good news is many of these collections have been (or are in the process of being) transferred to the Historical Archives of the European Union (HAEU) at the European University Institute in Florence. ${ }^{26}$ They are housed in the Villa Salviati, a beautiful building with a colorful history. Many EU archives thus exist at more than one institution: originals may be kept at the contributing organization and copies sent to the HAEU; or microforms or digital copies may be kept at the contributing institution with originals sent to HAEU. Consolidation and redundancy represent the best of both worlds: researchers wishing to examine the archives of different EU institutions do not have to travel to multiple locations, and preservation is enhanced through redundancy. HAEU also serves as an archive for the "private papers of key European politicians, high-ranking EU officials, and individuals involved in the process of European integration as well as the archives of pro-European movements and other organizations with a European scope" resulting in a one-stop archive for the history of European integration. ${ }^{27}$

The HAEU has a helpful online research guide, organized by topic. The search engine has a much-needed language limit (there is even a category for "American English"). Since many collections were originally housed in French archives, most are described using French metadata regardless of the original language(s). For this reason, searching (not browsing) is the optimal strategy since documents created in English, Dutch, Italian, German, etc., may have an abstract in the original language, while the fonds and series will have French titles (additional language metadata would be helpful and hopefully there are plans for this). The archives also contain impressive collections of oral histories, audiovisual collections, digital files, and a reference library. HAEU even conducts educational and outreach programs. There is much to admire about this institution, which clearly has the support of the EU and seems both wellfunded and celebrated.

\section{Conclusion}

This column has only touched on the scope and AI policies of a limited number of IGO archives- to do this justice, a book could be written. But one can't help but question the contradictions: UNESCO just celebrated "International Day for Universal Access to Information," and their archival website is clear and comprehensive. But many IGOs, particularly in the UN, have policies both mysterious and antiquated. As late as 2015 the UN Food and Agriculture Organization required researchers to make appointments to use the archives via their FAO Ambassadors, which was nowhere explained on the website. ${ }^{28}$ The ILO archives website has contact information and a brief description of its contents, but the link to "Rules for Access to the ILO Historical Archives" is broken. The UNCEF archives are closed. The GATT/WTO archives only provides a brief description of its content with a cryptic note that "access limited to authorized users." ${ }^{29}$ And some IGOs mention virtually nothing about their archives. The 1999 UNESCO publication cited earlier notes that the archives of the International Fund for Agricultural Development (a UN Specialized agency dedicated to helping the rural poor) "are open only to internal staff and the staff of other international organizations." ${ }^{30}$ I can now find no other trace of its existence.

It can be difficult for even the most dedicated and credentialed IGO researcher to determine what information they are entitled to and how to access it (just think of the challenges a member of the public faces). Some of this may be due to financial constraints and staff limitations, but judging from the report by the Special Rapporteur it also sounds like institutional culture and lack of transparency. Kaye notes with dismay that "despite extensive outreach, dozens of intergovernmental organizations and agencies within the United Nations system did not respond to the mandate's call for submission. I was particularly disappointed not to receive a submission from the Secretariat of the United Nations Headquarters in New York." ${ }^{31}$ Despite a climate of open government policies now being embraced around the world, many IGOs seem resistant to change.

\section{References and Notes}

1. "Knowledge Without Limits? On Data, Archival Access, Copyright, and Global Commons in Inter-national Relations Research" (Annual Congress Program, International Studies Association, Toronto, 2019), http:// web.isanet.org/Web/Conferences/Toronto\%202019-s /Toronto\%202019\%20-\%20Full\%20Program.pdf.

2. "Strengthening Policy Research Uptake in the Context of the 2030 Agenda for Sustainable Development," Joint Inspection Unit of the United Nations System, UN Doc Symbol JIU/REP/2018/7, accessed September 23, 2019, https://www.unjiu.org/content/strengthening 


\section{In Larger Freedom}

-policy-research-uptake-context-2030-agenda-sustain able-development.

3. "Strengthening Policy Research Uptake in the Context of the 2030 Agenda for Sustainable Development."

4. Judy H. Peterson, "CWIHP Archives Update: Access to Archives of Intergovernmental Organizations," Wilson Center, January 15, 2005, https://www.wilsoncenter.org /article/cwihp-archives-update-access-to-archives-inter governmental-organizations.

5. "Beyond the Archives," United Nations Archives and Records Management, https://archives.un.org/content lexternal-resources.

6. International Council on Archives, https://www.ica.org/en.

7. See the 1999 version at https://unesdoc.unesco.org lark:/48223/pf0000115937.

8. "Guide to the Archives of Intergovernmental Organizations-UNESCO Digital Library," document code: CII.99/WS/2, p. 299, https://unesdoc.unesco.org/ark: /48223/pf0000115937.

9. "Access to Information Policy Overview," World Bank, https://www.worldbank.org/en/access-to-information loverview\#1.

10. "Where Global Solutions Are Shaped for You | Library and Archives | Access Rules," United Nations Office in Geneva, https://www.unog.ch/80256EE60057D930/(http Pages)/F43B10BD2DF0D7B4C1257C850047F251?Open Document.

11. The archives include "inter-agency relations" or correspondence of Secretaries General with external agencies and documents related to projects between them.

12. "Information Sensitivity, Classification and Handling," United Nations, Secretary General's Bulletin, UN Doc Symbol ST/SGB/2007/6, https://undocs.org/ST /SGB/2007/6.

13. See https://archives.un.org/sites/archives.un.org/files/6 -guidance_sensitive_information.pdf.

14. "United Nations Information Sensitivity Toolkit, Version 1," United Nations Archives and Records Management Section and United Nations Peacekeeping Information Management Unit, https://archives.un.org/sites/archives .un.org/files/RM-Guidelines/information_sensitivity _toolkit_2010.pdf.

15. "Criticisms of United Nations operations. Folder S-10650002-06," UN Office for Special Political Affairs, https:// search.archives.un.org/downloads/united-nations-office -for-special-political-affairs-1955-1991.pdf.
16. Ceasefire Agreement of 5 October 1995, Folder S-18350016-0005, United Nations, International Conference on the Former Yugoslavia (ICFY), https://search.archives .un.org/ceasefire-agreement-of-5-october-1995.

17. "Report of the Special Rapporteur on the Promotion and Protection of the Right to Freedom of Opinion and Expression," UN Doc Symbol A/72/350, United Nations General Assembly, 72nd Session, 18 August 2017, https:// undocs.org/A/72/350.

18. "General Comment No. 34, Article 19: Freedoms of Opinion and Expression, Paragraph 19," United Nations International Covenant on Civil and Political Rights, Human Rights Committee, 102nd session, Geneva, 11-29 July 2011, UN Docs Symbol CCPR/C/GC/34, https://www2 .ohchr.org/english/bodies/hrc/docs/gc34.pdf.

19. See http://pubdocs.worldbank.org/en/784321442508046 587/OpenArchivesAccessing theholdingsoftheWorld BankGrouparchives.pdf.

20. "World Bank Administrative Manual: Information Classification and Control Policy," World Bank, http:// pubdocs.worldbank.org/en/288241548255246039 /AMS-6-21A-Information-Classification-and-Control -Policy.pdf.

21. A search for "strictly confidential" on the World Bank archives results in 38 results, "confidential" in 198, and "partial disclosure" in 140, out of 35,552 records. This is negligible. By contrast, a search on the UN archives retrieves 73,752 results (out of 514,019) for the word "confidential" (14.3 percent) and 49,864 for "strictly confidential" (9.7 percent).

22. See https://europa.eu/european-union/documents-pub lications/libraries-archives_en.

23. "EU Council Regulation (EEC, Euratom) No 354/83 of 1 February 1983 concerning the opening to the public of the historical archives of the European Economic Community and the European Atomic Energy Community," EU Official Journal L 043, 15/02/1983, p. 1, https://eur -lex.europa.eu/LexUriServ/LexUriServ.do?uri=CELEX:3 1983R0354:EN:HTML.

24. "EC Regulation No 1049/2001 of the European Parliament and of the Council of 30 May 2001 Regarding Public Access to European Parliament, Council and Commission Documents," EU Official Journal L145, 31.5.2001, p. 43-48, https://eur-lex.europa.eu/legal-content/EN/ALL/?uri =celex\%3A32001R1049. 
25. See https://ec.europa.eu/info/about-european-commission /service-standards-and-principles/transparency/freedom -information_en.

26. See "Historical Archives of the European Union," European University Institute, https://www.eui.eu/Research /HistoricalArchivesOfEU.

27. "Holdings," Historical Archives of the European Union, European University Institute, https://archives.eui.eu.

28. The policy has since changed, and now permission can be obtained by emailing the FAO archives.
29. "WTO Paper Archive," World Trade Organization, https://docs.wto.org/gtd/Default.aspx?pagename=WTO paperarchive\&langue $=\mathrm{e}$.

30. "Guide to the Archives of Intergovernmental Organizations-UNESCO Digital Library," Document code: CII.99/WS/2, p. 149, https://unesdoc.unesco.org /ark:/48223/pf0000115937.

31. "Report of the Special Rapporteur on the Promotion and Protection of the Right to Freedom of Opinion and Eexpression.” 